Article

\title{
Efficacy of Compounds Isolated from Streptomyces olivaceus against the Morphogenesis and Virulence of Candida albicans
}

\author{
Lili Meng ${ }^{1,2, \dagger}$, Changli Sun ${ }^{3, \dagger}$, Chunyan Zhang ${ }^{3}$, Shihao Song ${ }^{1,2}$, Xiuyun Sun ${ }^{1,2}$, Jianhua Ju ${ }^{3}$ (i) \\ and Yinyue Deng $1, * \mathbb{D}$ \\ 1 School of Pharmaceutical Sciences (Shenzhen), Sun Yat-sen University, Guangzhou 510275, China \\ 2 College of Agriculture, South China Agricultural University, Guangzhou 510642, China \\ 3 CAS Key Laboratory of Tropical Marine Bio-Resources and Ecology, South China Sea Institute of Oceanology, \\ Chinese Academy of Sciences, 164 West Xingang Road, Guangzhou 510301, China \\ * Correspondence: yinyue_deng@hotmail.com; Tel.: +86-2085286471; Fax: +86-2085280203 \\ + These authors contributed equally to this work.
}

Received: 4 June 2019; Accepted: 24 July 2019; Published: 26 July 2019

check for updates

\begin{abstract}
Candida albicans is a type of commensal fungi which causes serious infections in immunocompromised patients and contributes to high mortality. In the present study, we identified that the extract from Streptomyces olivaceus SCSIO T05 inhibited hypha and biofilm formation of C. albicans. Seven compounds were isolated and evaluated for their effects on the biological functions and virulence of $C$. albicans. Two leading compounds, compound $\mathbf{1}$ (sorbicillin) and compound 2 (3-methyl-N-(2'-phenethyl)-butyrylamide) were identified as exhibiting strong activity against C. albicans morphological transition, adhesion activity, cytotoxicity, and adhesion to human cells, in a dose-dependent manner. Notably, compound 2 inhibited C. albicans infection in mouse oral mucosal models. Transcriptomic analysis and real-time PCR results revealed that compound 2 most likely inhibited the biological functions of $C$. albicans cells by regulating the expression levels of HWP1, TEC1, ALS1, IFD6, and CSH1, which are associated with filament formation and cell adhesion. Our results suggest that the candidate compounds present excellent efficacy against $C$. albicans pathogenicity and that they can be developed as potential options for the clinical treatment of candidiasis.
\end{abstract}

Keywords: Streptomyces olivaceus; Candida albicans; hypha formation; virulence

\section{Introduction}

The incidence of life-threatening infections caused by opportunistic fungi has increased sharply, and the most frequently encountered of these fungi is Candida albicans, accounting for $48 \%$ of the cases of bloodstream infections and contributing to a high mortality rate of $40 \%$ [1]. Unlike other commensal pathogens, C. albicans can survive in several distinct sites with different physiological pressures; therefore, various diseases may be caused when individuals are immunocompromised and debilitated $[2,3]$.

There exist at least three morphologies for this fungus: the yeast budding form, pseudohyphae, and the filamentous form [4]. C. albicans cells begin infection with adhesion to host cells in the yeast budding form, followed by transitions from yeast to hypha [4-7]. These transitions are considered to be essential to the virulence of $C$. albicans. Additionally, infections caused by $C$. albicans are complex and are related to many other virulence factors such as adhesins, thigmotropism, and secretion of hydrolases [8]. Gradually, the hyphal form develops into spatially organized structures, namely biofilms, which are complex structures consisting of cells surrounded by exopolymeric matrices [9]. 
Candida biofilm formation has serious repercussions due to the notorious resistance of these biofilms to antifungal drugs and their negative impacts on implanted medical devices [10-12].

In recent decades, investigations have revealed that morphogenesis of $C$. albicans is mainly determined by environmental signals $[13,14]$. Furthermore, two well-characterized signaling pathways underlying the morphological changes are the cAMP-protein kinase A (PKA) pathway and the mitogen-activated protein kinase (MAPK) pathway. In these two pathways, HWP1 is a type of cell wall protein that is critical for cellular adhesion and filamentous formation [13,15,16]; EFG1 is a transcription factor that is activated by the PKA pathway and interacts directly with hypha-specific promoters during filament development $[17,18]$; and TEC1, which is regulated by EFG1, also induces filamentous formation [19]. The regulatory networks are also involved in cell adhesion. The ALS gene family, which encodes a large number of cell surface glycoproteins, plays an important role in Candida adherence to host cell surfaces $[20,21]$.

The deep-sea strain Streptomyces olivaceus SCSIO T05 was isolated from a sediment sample collected from the Indian Ocean. Chemical investigation led to the isolation of anthracene scaffolds and xiamycins from the wild-type strain [22]. The mutant strain S. olivaceus SCSIO T05 $\Delta \mathrm{rsdK} 2 / \Delta \mathrm{xmcP}$ was constructed for enhanced production of ansamycins [23]. Intriguingly, we found that the crude extract from the mutant strain exhibited strong inhibitory activity against the yeast-to-hypha transition and adhesion of C. albicans. In this study, seven compounds including sorbicillin (1), 3-methyl- $N-\left(2^{\prime}\right.$-phenylethyl) butyramide (2), 2-methyl- $N$-(2'-phenylethyl)-butyramide (3), cyclo-(L-Val-L-Pro) (4), cyclo-(L-Ile-L-Pro) (5), cyclo-(L-Leu-L-Pro) (6), and cyclo-(1-Phe-L-Pro) (7), were isolated and identified by comparing their MS and NMR data with those previously reported [24,25]. Among these compounds, sorbicillin (compound 1) and 3-methyl- $\mathrm{N}$-(2'-phenylethyl)-butyramide (compound 2) exhibited excellent efficacy against yeast-to-hypha transition and adhesion of C. albicans. Additionally, these two compounds inhibited the virulence of $C$. albicans toward a human cell line, and compound 2 showed good inhibitory activity in mouse infection models. In general, our findings suggest that the two compounds are potential novel antifungal agents against mucosal candidiasis.

\section{Results}

\subsection{Extract of S. olivaceus SCSIO T05 $\Delta r s d K 2 / \Delta x m c P$ Inhibits Hypha Formation and Adhesion of C. albicans}

For C. albicans, morphogenesis of the yeast-to-hypha transition is considered a key virulence factor, and adhesion is the first step for biofilm formation. To determine whether there are some active compounds from $S$. olivaceus that exhibit efficacy against $C$. albicans, we obtained crude extracts of compounds from S. olivaceus SCSIO T05 rsdK2/xmcP and tested the effects of the extracts on morphology and adhesion in C. albicans. The crude extract decreased filament formation in C. albicans by $94.96 \pm 0.82 \%$ and $75.16 \pm 0.82 \%$ when added at final concentrations of $500 \mu \mathrm{g} / \mathrm{mL}$ and $250 \mu \mathrm{g} / \mathrm{mL}$, respectively (Figure 1A,B). Intriguingly, the extract also inhibited Candida adhesion activity to $13.07 \pm 1.75 \%, 24.95 \pm 1.86 \%$, and $58.52 \pm 4.64 \%$ of that observed in the untreated control when added at lower final concentrations of $100 \mu \mathrm{g} / \mathrm{mL}, 50 \mu \mathrm{g} / \mathrm{mL}$, and $25 \mu \mathrm{g} / \mathrm{mL}$, respectively (Figure 1C).

\subsection{Isolation of Active Compounds from the Extract}

All isolated compounds (1-7, Figure 2 and Table S1) were evaluated for antifungal activity. Among these, compounds $\mathbf{1}$ and $\mathbf{2}$ exhibited excellent efficacy in the inhibition of the yeast-to-hypha transition of $C$. albicans and decreased the hyphal formation rates to $0 \%$ at $100 \mu \mathrm{g} / \mathrm{mL}$ (Figure $3 \mathrm{~A}-\mathrm{C}$ ). In the adhesion assays, compounds $1-3$ and compound 7 exhibited strong inhibition against $C$. albicans at $100 \mu \mathrm{g} / \mathrm{mL}$ (Figure 3C). We investigated whether the two compounds affected the colony morphology of C. albicans. As shown in Figure 3D, similar to the effects on filament formation, the two compounds also clearly altered the colony morphology of $C$. albicans. There were numerous hyphae around the margins of the C. albicans cell colonies that disappeared in the presence of the two compounds (Figure 3D). 
Moreover, the addition of compounds $\mathbf{1}$ or $\mathbf{2}$ also altered the colonies of C. albicans from wrinkled to smooth (Figure 3D).
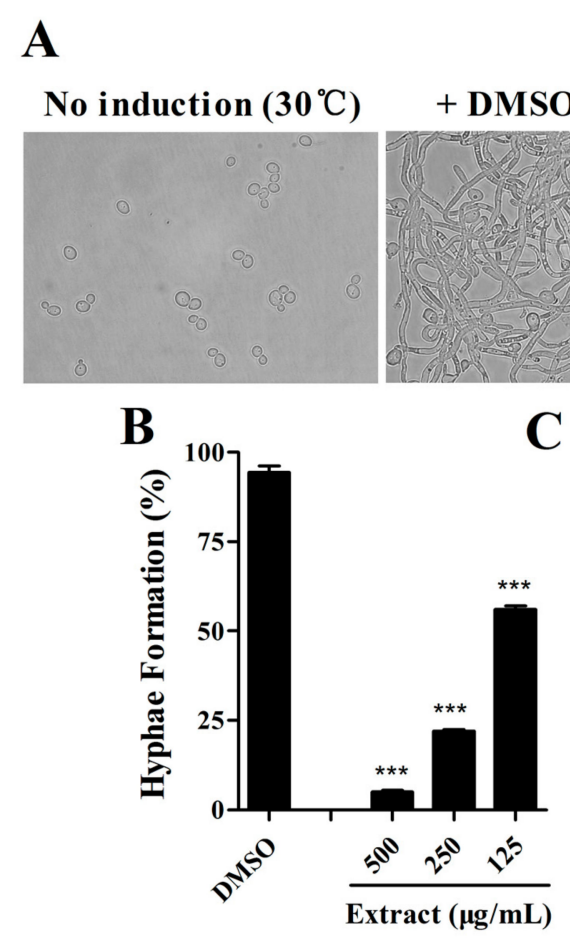

C
$+\operatorname{DMSO}\left(37^{\circ} \mathrm{C}\right)$

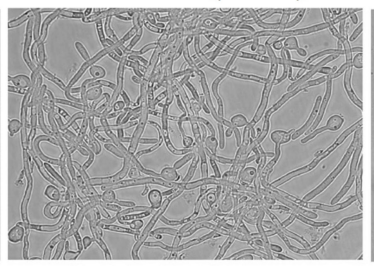

+ Extract $(500 \mu \mathrm{g} / \mathrm{mL})$ $\left(37^{\circ} \mathrm{C}\right)$

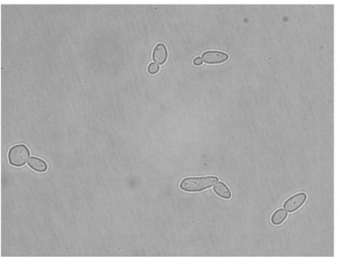

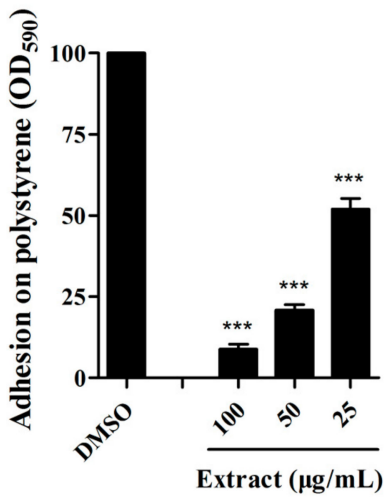

Figure 1. Effects of the extract from Streptomyces olivaceus SCSIO T05 $\Delta \mathrm{rsdK} 2 / \Delta \mathrm{xmcP}$ on hypha formation in Candida albicans. Candida cells were grown under noninductive conditions $\left(30^{\circ} \mathrm{C}\right)$ or with induction $\left(37^{\circ} \mathrm{C}\right)$. The photographs were taken $6 \mathrm{~h}$ after induction $(\mathrm{A})$, and hypha formation rates were calculated (B). Efficacy of the extract against adhesion of C. albicans at $100 \mu \mathrm{g} / \mathrm{mL}, 50 \mu \mathrm{g} / \mathrm{mL}$ and $25 \mu \mathrm{g} / \mathrm{mL}$, respectively $(\mathbf{C})$. The data represent the means \pm standard deviations of three independent experiments. $* * *, p<0.001$ (unpaired $t$-test).<smiles>C/C=C/C=C/C(=O)c1cc(C)c(O)c(C)c1O</smiles><smiles>CC(C)CC(=O)NCCc1ccccc1</smiles><smiles>CCC(C)C(=O)NCCc1ccccc1</smiles><smiles>CC(C)[C@H]1NC(=O)C2CCCN2C1=O</smiles><smiles>CCC(C)C1NC(=O)[C@@H]2CCCN2C1=O</smiles><smiles>CC(C)CC1NC(=O)[C@@H]2CCCN2C1=O</smiles><smiles>O=C1NC(Cc2ccccc2)C(=O)N2CCC[C@H]12</smiles>

Figure 2. Structures of compounds 1-7 isolated from the extract of S. olivaceus.

\subsection{Effects of Isolated Compounds on the Cytotoxicity of C. albicans}

Cytotoxicity was measured by quantifying the release of lactate dehydrogenase (LDH) into the supernatants of a human cell line, A549. To assess the effects of candidate compounds on the pathogenicity of $C$. albicans, we then continued to investigate whether these compounds affected C. albicans cytotoxicity to A549 cells. The results shown in Figure 4A suggest that compounds 1, 2, and $3(100 \mu \mathrm{g} / \mathrm{mL})$ did not exhibit toxic effects on A549 cells at a concentration of $100 \mu \mathrm{g} / \mathrm{mL}$. However, 
these three compounds were capable of attenuating the cytotoxicity of $C$. albicans, and exogenous addition of the same concentration of these compounds reduced C. albicans virulence by $79.09 \pm 3.53 \%$, $100.00 \%$, and $58.44 \pm 5.45 \%$, respectively (Figure $4 \mathrm{~B}$ ).
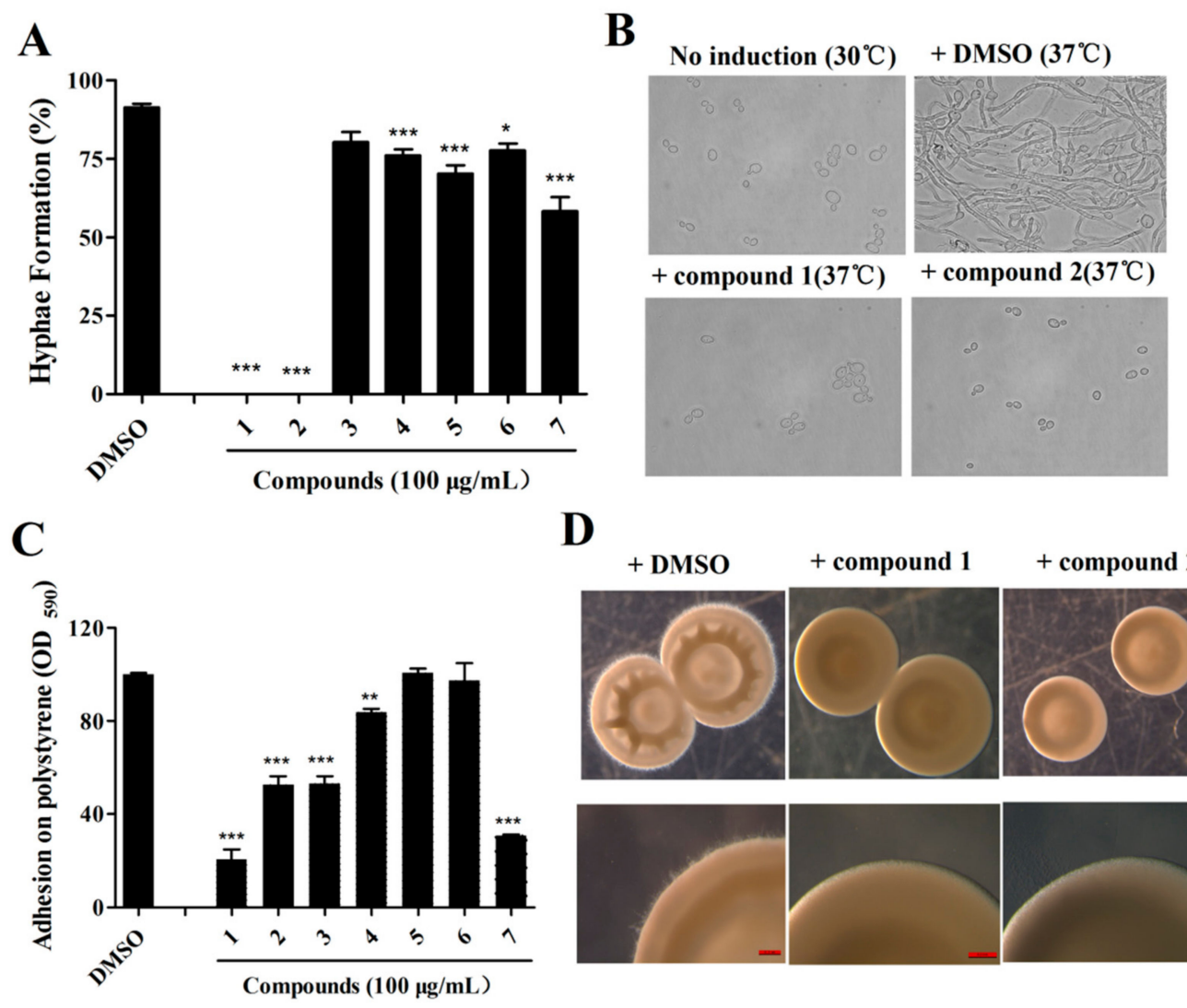

\section{D}

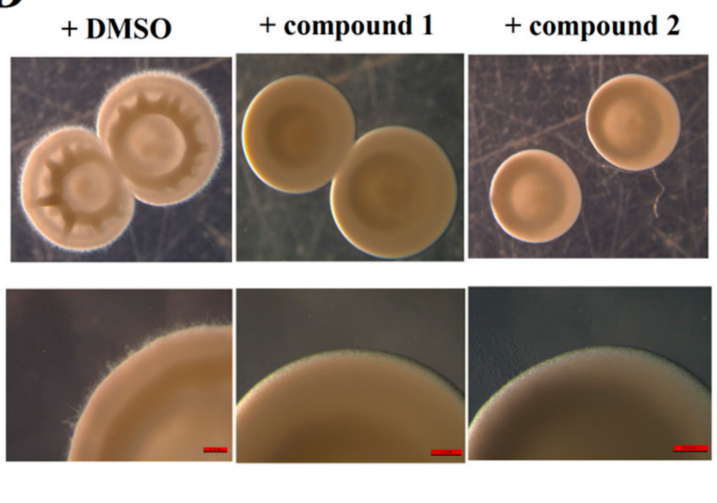

Figure 3. Effects of compounds isolated from the extract of S. olivaceus on hypha formation and adhesion of C. albicans. (A) Effects of isolated compounds on the hyphal formation of C. albicans SC5314 at $100 \mu \mathrm{g} / \mathrm{mL}$. (B) Photograph of C. albicans SC5314 cells, which were grown under noninductive conditions $\left(30^{\circ} \mathrm{C}\right)$, or with induction $\left(37^{\circ} \mathrm{C}\right)$, with or without compounds $\mathbf{1}$ or 2 at $100 \mu \mathrm{g} / \mathrm{mL}$. (C) Effects of isolated compounds on adhesion assays of C. albicans SC5314 at $100 \mu \mathrm{g} / \mathrm{mL}$. (D) Colony morphology of C. albicans treated with compounds $\mathbf{1}$ and 2 at $100 \mu \mathrm{g} / \mathrm{mL}$ on Spider agar plates with DMSO as a control. The data represent the means \pm standard deviations of three independent experiments. ${ }^{*}, p<0.05 ;{ }^{* *}, p<0.01 ;{ }^{* * *}, p<0.001$ (unpaired $t$-test).

\subsection{The Effects of Compound $\mathbf{1}$ and $\mathbf{2}$ on C. albicans Are Dose-Dependent}

Due to the excellent activity of compounds $\mathbf{1}$ and $\mathbf{2}$ in the reduction of the yeast-to-hypha transition, adhesion, and cytotoxicity of C. albicans SC5314 cells, we then investigated whether these two compounds affected C. albicans in a dose-dependent manner. Gradient concentrations of compounds $\mathbf{1}$ and $\mathbf{2}$ were assessed for inhibitory activity against $C$. albicans. The two compounds exhibited dose-dependent effects on the hypha formation, adhesion assays, and cytotoxicity (Figure 5A-D). In particular, compounds 1 and 2 inhibited the virulence of $C$. albicans by $67.25 \pm 3.84 \%$ and $53.49 \pm 5.71 \%$, respectively, at a final concentration of $50 \mu \mathrm{g} / \mathrm{mL}$ (Figure 5D). Analysis of the growth rates indicated that compound 2 hardly influenced the growth of $C$. albicans at $100 \mu \mathrm{g} / \mathrm{mL}$, while compound 1 partially inhibited this fungus growth at a final concentration of $50 \mu \mathrm{g} / \mathrm{mL}$ (Figure S2). 
A

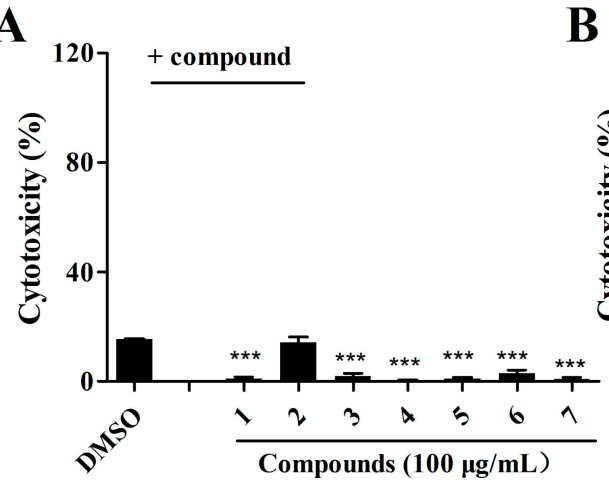

B

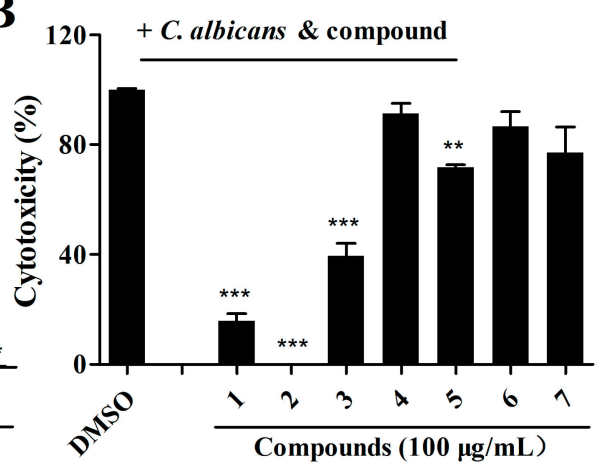

Figure 4. Effects of the isolated compounds on C. albicans virulence using the cell line A549. (A) Analysis of the toxicity of compounds toward A549 cells. The compounds were dissolved in DMSO, and the amount of DMSO used as the solvent for the compounds was used as a control. (B) Analysis of the effects of the compounds on the cytotoxicity of $C$. albicans toward A549 cells. Cytotoxicity was detected and measured as lactate dehydrogenase (LDH) release. The LDH released by A549 cells after inoculation with C. albicans in the absence of compounds was defined as $100 \%$ to normalize the LDH release ratios of the other treatments. The data represent the means \pm standard deviations of three independent experiments. ${ }^{* *}, p<0.01 ;{ }^{* *}, p<0.001$ (unpaired $t$-test).

A

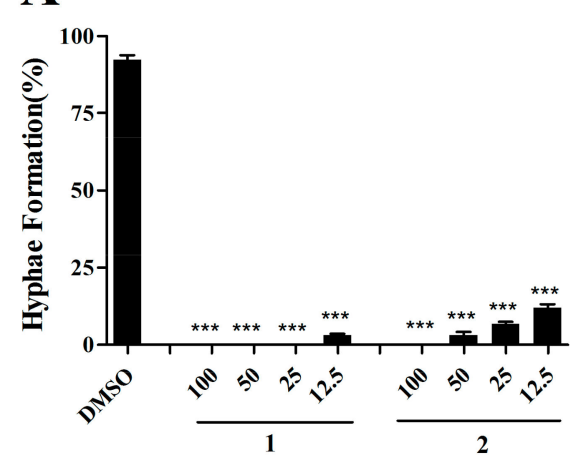

C

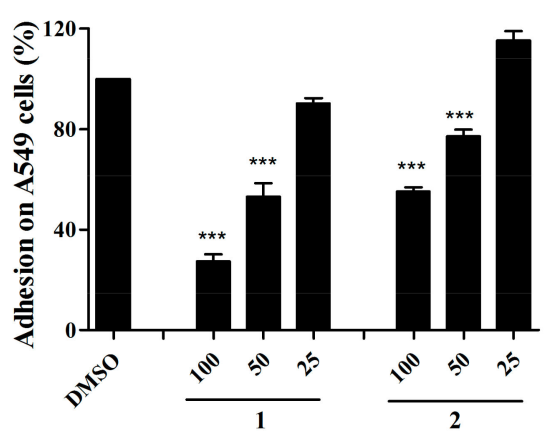

Compounds $(\mu \mathrm{g} / \mathrm{mL})$

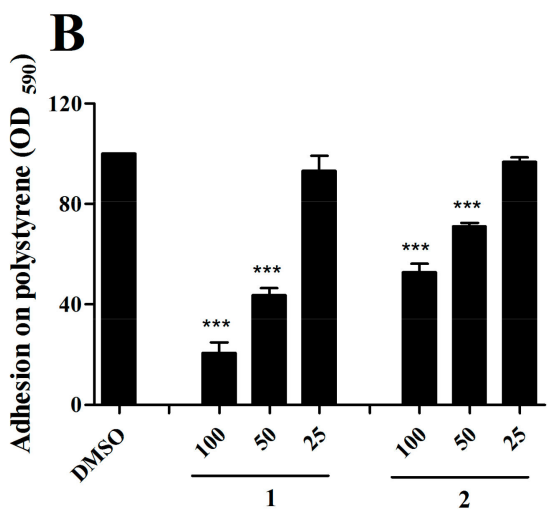

D

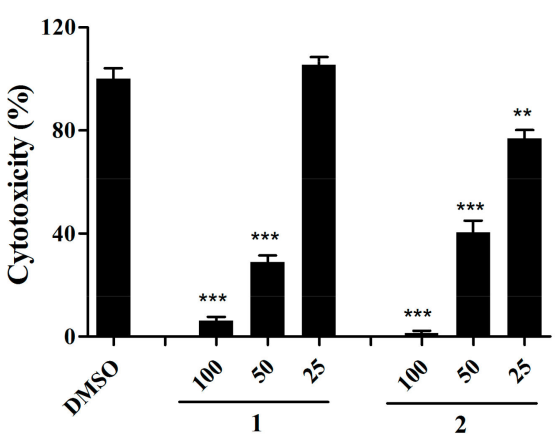

Compounds ( $\mu \mathrm{g} / \mathrm{mL})$

Figure 5. Effects of the candidate compounds on hypha formation (A), adhesion on polystyrene (B), adhesion on epithelial cell A549 (C), and cytotoxicity (D) assays at gradient concentrations of $100 \mu \mathrm{g} / \mathrm{mL}$, $50 \mu \mathrm{g} / \mathrm{mL}$, and $25 \mu \mathrm{g} / \mathrm{mL}$. The data represent the means \pm standard deviations of three independent experiments. ${ }^{* *}, p<0.01 ;{ }^{* *}, p<0.001$ (unpaired $t$-test). 


\subsection{Compound 2 Reduced C. albicans Infection in the Mouse Oral Mucosal Infection Model}

Due to the fact that compound 2 did not inhibit the growth of $C$. albicans cells, we continued to investigate the effects of compound $\mathbf{2}$ in vivo using a mouse oral mucosal infection model. Treatment with compound 2 significantly inhibited the number of $C$. albicans cells aggregated in the pathological tissues compared to tissues infected with only fungus (Figure 6A,B). Measurement of the fungus colony-forming units (CFUs) in the mouse tongues revealed that the addition of $100 \mu \mathrm{g} / \mathrm{mL}$ of compound 2 decreased the CFU count from $1.4 \times 10^{5}$ to 22 at five days post-inoculation (Figure $6 \mathrm{~B}$ ).

A

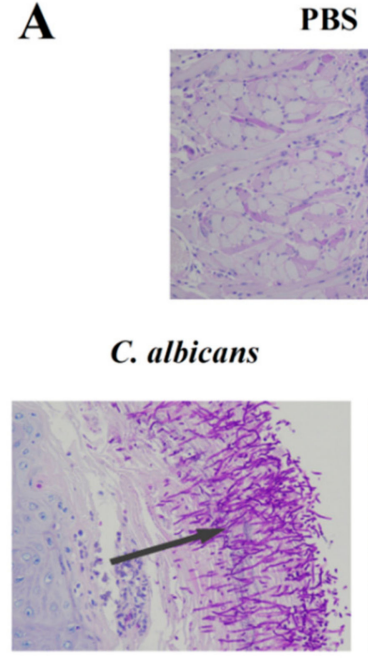

PBS

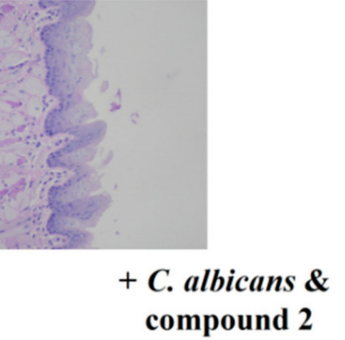
compound 2

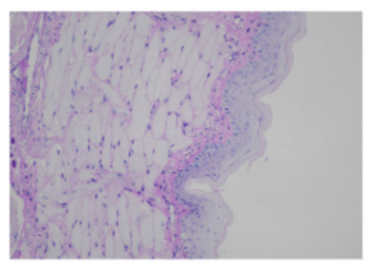

B

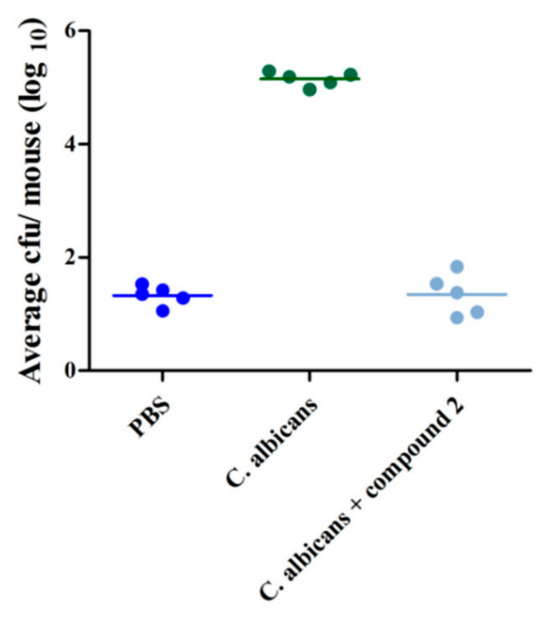

Figure 6. Efficacy of compound $2(100 \mu \mathrm{g} / \mathrm{mL})$ against C. albicans SC5314 in the mouse oral mucosal infection model. Pathological sections were evaluated to determine the effect on C. albicans infection (A). The in vivo pathogen cell numbers of C. albicans SC5314 in the mouse tongues after infection in the absence and presence of compound 2 (B).

\subsection{Compound 2 Affected the Expression Levels of a Wide Range of Genes in C. albicans}

To determine the effect of compound 2 on the gene expression profile of $C$. albicans, we analyzed and compared the transcriptome profiles of the C. albicans wild-type SC5314 strain cultured in the presence and absence of compound 2 using RNA-seq. Differential gene expression analysis identified 220 genes with a $\log _{2}$ fold change $\geq 1.5$ in the wild-type strain SC5314 upon the addition of $100 \mu \mathrm{g} / \mathrm{mL}$ of compound 2 (Figure 7A and Table S2). These differentially expressed genes are related to a wide range of biological functions such as transcriptional regulation, membrane components, signal transduction, motility, flagellum synthesis, stress tolerance, metabolism, and virulence (Figure 7A and Table S2). Quantitative RT-PCR analysis of the selected genes confirmed the RNA-seq results (Figure 7B,C). Intriguingly, GO term analysis indicated that many of these genes are involved in hypha formation and biofilm formation, such as the downregulated genes HWP1, TEC1, and ALS1, which have been well studied in C. albicans based on previous investigations (Figure 7C,D). In addition, our results suggested that the candidate compound may inhibit the pathogenesis of $C$. albicans via a complex signaling network (Figure 7C,D). 

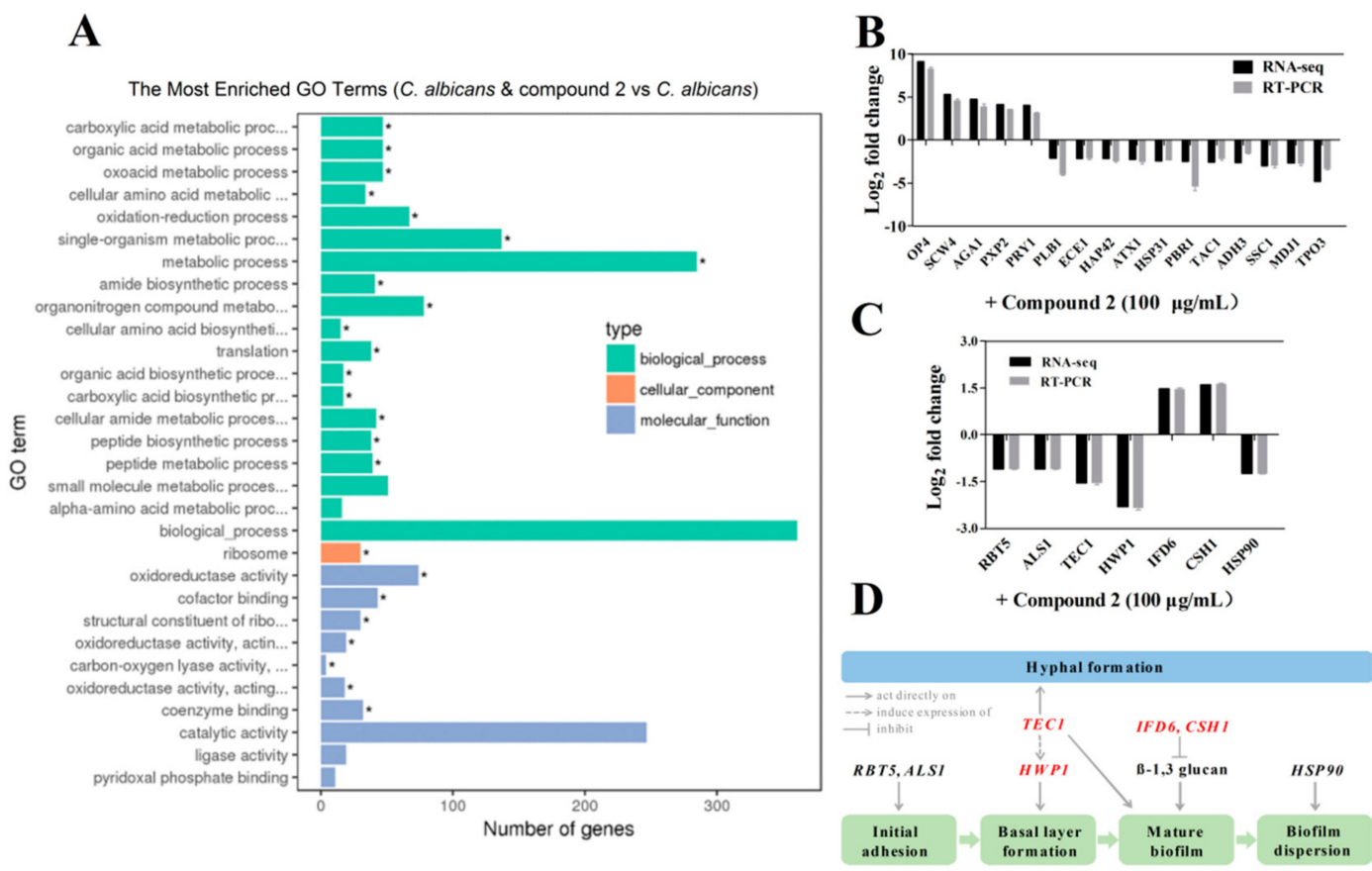

Figure 7. Differential gene expression profiles of C. albicans treated with compound $2(100 \mu \mathrm{g} / \mathrm{mL})$. GO term enrichment analysis of gene expression levels measured by RNA-seq (A). qRT-PCR analysis of the selected genes confirmed the RNA-seq results (B). Effect of compound $\mathbf{2}$ on the expression levels of genes associated with morphogenesis, adhesion and biofilm formation (C). Schematic diagram of the signaling pathways that govern each phase of biofilm formation and morphogenesis in C. albicans affected by compound 2 (D). The data represent the means \pm standard deviations of three independent experiments. *, the enriched GO term.

\section{Discussion}

C. albicans is the most common opportunistic human pathogen and may cause fatal infections in patients with immune deficiency [26]. Unlike other fungal pathogens that infect only some specific sites, C. albicans can survive as a commensal in several anatomically different sites, can switch between yeast and hypha forms in response to environmental changes [2,26], and gradually forms biofilm. Morphogenesis is regarded as a key virulence factor, and biofilms are intrinsically resistant to antifungal drugs such as amphotericin B, azoles, and echinocandin, while adhesion is the inceptive phase of mature biofilm formation [27]. As the development of new drugs using traditional target-based methods is associated with low productivity, there has been increased interest in new therapeutics and strategies to treat fungal diseases $[27,28]$. Therefore, overcoming the increasing drug resistance of Candida is a challenge worldwide.

As most antibiotics are produced by actinomycetes, we focused on the investigation of the antifungal activity of metabolites of $S$. olivaceus. The aim of this study was to estimate the anti-Candida activity of the seven compounds isolated from S. olivaceus SCSIO T05 $\Delta \mathrm{rsdK} 2 / \Delta \mathrm{xmcP}$ because the extract of this strain exhibited excellent inhibition of yeast-to-hypha transition and adhesion at regular screening concentrations (Figure 1; Figure 2). Compounds 1 and $2(100 \mu \mathrm{g} / \mathrm{mL})$ exhibited strong inhibition of morphological transition, adhesion, and cytotoxicity in a dosage-dependent manner (Figure 3; Figure 4; Figure 5). A prior study identified that sorbicillin (compound 1) can be isolated from Penicillium spp. and has good bioactivity and wide pharmaceutical applications [29]; however, the characteristics of compound $\mathbf{2}$ are not clear. Nowadays, sharply increasing drug resistance is a serious problem. To treat the infections caused by microorganisms, people take antibiotics which usually kill microbes or inhibit their growth. In this way, antibiotics induce enormous environmental pressure. Previous investigations have asserted that drug resistance is natural selection in that 
microorganisms able to avoid the pressure will be the ones to propagate with resistance genes and gradually, drug resistance phenomena emerge [30]. Given the rapid spread of drug resistance [30,31], agents that are virulence inhibitors rather than fungicides are urgently required; that is, agents which do not inhibit the growth of pathogen cells. Our findings indicated that compound $\mathbf{2}$ showed almost no inhibition of the growth of C. albicans at $100 \mu \mathrm{g} / \mathrm{mL}$ (Figure S2) but displayed excellent inhibitory activity against $C$. albicans in vitro $(100 \mu \mathrm{g} / \mathrm{mL})$ and effectively prevented Candida infection in mouse oral tissue. In addition, the transcriptomic profile results of $C$. albicans in the absence and presence of compound 2 revealed that compound 2 interfered with the expression of some important proteins, namely Hwp1, TEC1, IFD6, and CSH1, which are associated with hypha formation and biofilm formation [20,32-37]. These results suggested that compound 2 might be a good candidate for the development of new antivirulence and antibiofilm agents against $C$. albicans diseases.

Interestingly, compound 2 was reported as an inhibitor of quorum sensing (QS)-controlled phenotypes in the gram-negative bacterium Vibrio harveyi, and this characteristic may be attributed to the effect of compound 2 on the QS systems of this pathogen [38]. As the phenotypes affected by compound 2 in C. albicans were linked to QS signals produced by C. albicans cells [13], compound 2 may have some influence on QS in C. albicans, and this aspect needs further investigation. Furthermore, the simple structure of compound 2 makes it very easy to produce by chemical synthesis. This compound can be obtained by a one-step chemical reaction of 3-methyl-butyric acid with phenylethylamine. The biosynthetic gene cluster and biosynthetic pathway of compound 2 can be assigned by bioinformatics analysis as the genome sequence of $S$. olivaceus has been identified [22,23]. The application of molecular biological, biochemical, and microbiological tools can also enhance the production of this compound. Therefore, we hypothesize that compound $\mathbf{2}$ may be a potentially promising antifungal drug. However, more work will be performed in the future to overcome some defects in our study; for example, to test the efficacy of compound $\mathbf{2}$ on the systemic infection model, and for the mouse mucosal model, infection followed by compound treatment will be more convincing.

\section{Materials and Methods}

\subsection{General Experimental Procedures}

NMR spectra were acquired with an AVANCE 500 spectrometer (Bruker, Zurich, Switzerland) or AVANCE HD 700 spectrometer (Bruker, Zurich, Switzerland) with TMS as the internal standard. Chemical shifts $(\delta)$ were expressed in ppm with reference to the solvent signals. Mass spectral data were obtained on a MaXis quadrupole-time-of-flight mass spectrometer (Bruker, Zurich, Switzerland). Silica gel (100-200 mesh, Yantai Jiangyou Silica Gel Development Co., Ltd., Yantai, China) and an RP-18 column (40-63 $\mu \mathrm{m}$, Millipore, Massachusetts, USA) were applied for column chromatography (CC). An Agilent 1260 liquid chromatograph (Agilent Technologies Inc., California, USA) with a diode array detector (DAD) and a YMC-Pack ODS-A column $(250 \times 20 \mathrm{~mm}, 5 \mu \mathrm{m})$ was used for semipreparative HPLC.

\subsection{Strains and Reagents}

C. albicans SC5314 (ATCC ${ }^{\circledR}$ MYA-2876TM) was grown and maintained in YPD medium (1\% yeast extract, $2 \%$ peptone, $2 \%$ glucose) at $30^{\circ} \mathrm{C}$ with shaking at $200 \mathrm{rpm}(4 \mathrm{~g})$. The compounds were dissolved in dimethyl sulfoxide (DMSO, Sigma, Shanghai, China) $(10 \mathrm{mg} / \mathrm{mL})$ and stored at $4{ }^{\circ} \mathrm{C}$. The wild-type strain of SCSIO T05 was isolated from a sediment sample collected from the Indian Ocean at $\mathrm{E} 94^{\circ} 3364^{\prime}$ and $\mathrm{S} 1^{\circ} 4256^{\prime}$ at a depth of $4617 \mathrm{~m}$, which was identified as S. olivaceus due to its $16 \mathrm{~S}$ rRNA gene sequence analyses and comparisons with other established sequences. The 16S rDNA gene sequence has been deposited with GenBank (accession number MF429815). The mutant strain S. olivaceus SCSIO T05 $\Delta \mathrm{rsdK} 2 / \Delta \mathrm{xmcP}$ was constructed by gene disruption [23]. 


\subsection{Fermentation and Isolation}

The fermentation procedure of the mutant strain was as described previously [23]. The entire culture broth $(40 \mathrm{~L})$ was harvested and filtered to yield the mycelium cake and liquid broth. The mycelium cake was extracted by ultrasonication with acetone, and the liquid broth was extracted with butanone. The acetone layer and butanone layer were evaporated to dryness to yield two residues, respectively. The two residues were combined after HPLC analysis and subjected to silica gel CC using gradient elution with $\mathrm{CHCl}_{3}$ and $\mathrm{MeOH}$ mixtures (100:0, 95:5, 90:10, 85:15, 80:20, 70:30, 50:50) to obtain seven fractions (Fr.1-Fr.7). Fr.2 was subjected to Rp-18 CC and eluted with $\mathrm{MeCN}-\mathrm{H}_{2} \mathrm{O}$ $(30: 70 \rightarrow 100: 0,0 \rightarrow 120 \mathrm{~min}$ ) to afford five fractions (Fr.2-1-Fr.2-5). Compound $\mathbf{1}(5.0 \mathrm{mg}$ ) was yielded by semipreparative HPLC $\left(\mathrm{MeCN}_{-} \mathrm{H}_{2} \mathrm{O}, 5: 5 \rightarrow 10: 0,0 \rightarrow 30 \mathrm{~min}\right)$ from Fr.2-1; Fr.3 was separated by Rp-18 CC with $\mathrm{MeCN}-\mathrm{H}_{2} \mathrm{O}(5: 95 \rightarrow 100: 0,0 \rightarrow 120 \mathrm{~min})$ to afford five fractions (Fr.3-1-Fr.3-5). Fr.3-2 was subjected to semipreparative HPLC (MeCN-H $\left.{ }_{2} \mathrm{O}, 10: 90\right)$ to yield compound $3(1.9 \mathrm{mg})$. Compounds 5-7 $(7.3 \mathrm{mg}$, $11.2 \mathrm{mg}$, 8.0 mg, respectively) were obtained by semipreparative HPLC (MeCN- $\left.\mathrm{H}_{2} \mathrm{O}, 15: 85,18: 82\right)$

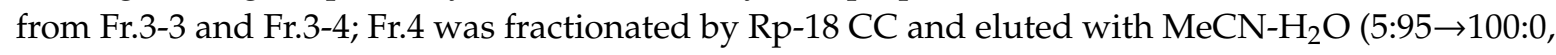
$0 \rightarrow 120 \mathrm{~min}$ ) to afford four fractions (Fr.4-1-Fr.4-4), and Fr.4-2 was separated by semipreparative HPLC ( $\left.\mathrm{MeCN}-\mathrm{H}_{2} \mathrm{O}, 15: 85\right)$ to obtain compound 4 (5.4 mg); Fr.5 was subjected to Rp-18 CC and eluted with

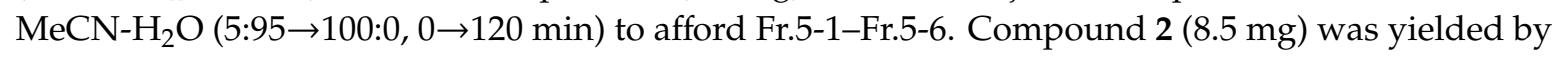
semipreparative HPLC $\left(\mathrm{MeCN}-\mathrm{H}_{2} \mathrm{O}, 30: 70\right)$ from Fr.5-2.

\subsection{Adhesion Assays}

With modifications of the previous published protocol [5,39], adhesion of C. albicans on polystyrene was examined in the presence or absence of compounds, with DMSO as a negative control and cell-free wells as a blank control. Overnight culture cells were diluted to an optical density $\left(\mathrm{OD}_{600}\right)$ of 0.5 using fresh glucose minimal medium (GMM; $6.7 \mathrm{~g}$ Bacto yeast nitrogen base and $0.2 \%$ glucose per liter). A $200-\mu \mathrm{L}$ aliquot of cell suspension with compound $(100 \mu \mathrm{g} / \mathrm{mL})$ was added into a 96-well plate and incubated at $37^{\circ} \mathrm{C}$ for $4 \mathrm{~h}$. Candida cells were dyed with $0.5 \%$ crystal violet for $45 \mathrm{~min}$ and then washed with cold water to remove the dyestuff and planktonic cells. Each well was filled with $200 \mu \mathrm{L}$ of $75 \%$ ethyl alcohol and was measured for absorbance of the dye at $590 \mathrm{~nm}$.

\subsection{Cell Binding Assays}

To estimate the efficacy of compounds in the inhibition of adhesion on the epithelial cells of yeast cells, which was considered the first step of invasion, the human cell line A549 was employed for the measurement of adhesion ability, following the methods in the previous publications with small modifications $[5,40]$. The A549 cells $\left(5 \times 10^{3}\right.$ per well) were grown overnight in Dulbecco's modified Eagle's medium (DMEM) containing 10\% fetal bovine serum (FBS) on a 96-well tissue culture plate, then were washed with PBS (phosphate buffered saline) twice. Compound preparation and suspension was performed using the same method as described for the biofilm formation assay, using DMSO and GMM as controls. These 96-well plates were incubated at $37^{\circ} \mathrm{C}$ for $1.5 \mathrm{~h}$, followed by the same treatment as mentioned in the adhesion assays. Finally, cell binding on A549 cells was quantified by measuring the absorbance at $590 \mathrm{~nm}$.

\subsection{Hypha Formation Assays}

An overnight culture was diluted to an $\mathrm{OD}_{600}$ of 0.1 using fresh GMM [5]. After treatment with compounds $(100 \mu \mathrm{g} / \mathrm{mL})$ or DMSO, the cultures were cultivated at $37^{\circ} \mathrm{C}$ for $6 \mathrm{~h}$, the yeast cells were harvested by centrifugation at $5000 \mathrm{rpm}(2348 \times \mathrm{g})$ for $10 \mathrm{~min}$ and then observed directly under a Leica inverted fluorescence microscope (Leica, Wetzlar, Germany). 


\subsection{Colony Morphology Assays}

An overnight culture was diluted to $2 \times 10^{3}$ colony-forming units (CFUs)/mL and incubated on Spider medium agar plates ( $1 \%$ peptone, $1 \%$ mannitol, $0.2 \% \mathrm{~K}_{2} \mathrm{HPO}_{4}$, and $1.5 \%$ agar) containing compounds $(100 \mu \mathrm{g} / \mathrm{mL})$ or DMSO at $37^{\circ} \mathrm{C}$ for $24 \mathrm{~h} \mathrm{[5].} \mathrm{These} \mathrm{plates} \mathrm{were} \mathrm{visualized} \mathrm{directly} \mathrm{under} \mathrm{a}$ Leica DMi8 microscope (Leica, Wetzlar, Germany), and images were captured using a Nikon Coolpix digital camera (Nikon Corporation, Tokyo, Japan).

\subsection{Cytotoxicity Assays}

The A549 cells were cultured with the same method as in the adhesion assays $\left(1.5 \times 10^{4}\right.$ cells per well) [39]. Overnight cultures of C. albicans were diluted to an $\mathrm{OD}_{600}$ of 0.1 in DMEM containing $1 \%$ FBS, with or without the addition of compounds. By following the manufacturer's instructions for the cytoTox $96^{\circledR}$ non-radioactive cytotoxicity assay kit (Promega, Madison, WI, USA), cytotoxicity was determined by measuring the release of lactate dehydrogenase (LDH) into the supernatants at $490 \mathrm{~nm}$. The cytotoxicity of the compounds was tested using the same method.

\subsection{Cell Growth Analysis}

For this assay, $C$. albicans cells were incubated overnight and then freshly diluted to an $\mathrm{OD}_{600}$ of 0.05 using GMM. Then, $300-\mu \mathrm{L}$ aliquots of cell suspension containing compounds $(100 \mu \mathrm{g} / \mathrm{mL})$ were added to the plate in triplicate. Growth analysis was then performed on the Bioscreen-C automated growth analysis system (Oy Growth Curves Ab Ltd, Helsingfors, Finland) at $30^{\circ} \mathrm{C}$ for 2 days.

\subsection{Quantitative Real-Time PCR Analysis}

C. albicans cells were grown in GMM at $30{ }^{\circ} \mathrm{C}$ and then diluted in the same medium to an $\mathrm{OD}_{600}$ of 0.1 with the tested compounds $(100 \mu \mathrm{g} / \mathrm{mL})$, using DMSO as control. After incubation for $6 \mathrm{~h}$ at $37^{\circ} \mathrm{C}$, cells switched from yeast to hyphal form and then cell samples were collected and washed with PBS. Total RNA was extracted using an RNA extraction kit (Promega, Beijing, China) and quantified. cDNA was obtained via a reverse transcription reaction using a reverse transcription kit (TaKaRa Biotechnology, Dalian, China) with the primers shown in Table S3. In this experiment, $4 \mu \mathrm{L}$ of cDNA (10 ng/ $\mu \mathrm{L}$ ), $0.5 \mu \mathrm{L}$ forward primer, $0.5 \mu \mathrm{L}$ reverse primer, and $5 \mu \mathrm{L}$ SYBR qPCR master mix (Vazyme, Nanjing, China) were mixed for each well. Real-time PCR analysis was performed on a 7300Plus real-time PCR system (Applied Biosystems, Massachusetts, USA). GSP1, a housekeeping gene in this fungus, was used as the standard for other gene expression [41]. The target gene expression results were calculated using the comparative $\mathrm{CT}(\Delta \Delta \mathrm{CT})$ method. We performed this experiment in triplicate with four repeats for each sample. As for RNA-sequencing, we routinely extracted the RNA samples mentioned above and then RNA-seq analysis was carried out by the Novogene company (Beijing, China). We obtained our results based on the Illumina technique and Paired-end method [42].

\subsection{Mouse Oral Mucosal Assays}

The establishment of a mouse oral mucosal model was based on a published study with minor modifications [43,44]. In this experiment, 20-22 g male BaLB/c mice (3 mice per group; animal experiment permission number 2019-C004) were subcutaneously injected with hydrocortisone (225 mg/kg) dissolved in PBS containing 0.5\% Tween-20 on the first day. Then, on the following day, Candida cells were washed with Hank's balanced salt solution (Biohao Biotechnology Co., Ltd., Wuhan, China) and then twice with PBS. The cells were resuspended in PBS $\left(\mathrm{OD}_{600}=0.1\right.$, equal to $10^{6} \mathrm{CFU} / \mathrm{mL}$ ) in the absence or presence of candidate compounds at a final concentration of $100 \mu \mathrm{g} / \mathrm{mL}$. After intraperitoneal injection of about $70-80 \mu \mathrm{L} 0.1 \mathrm{~g} / \mathrm{mL}$ chloral hydrate (Yuanye Biotech, Shanghai, China), the anesthetized mice were placed on an isothermal mat maintained at $37^{\circ} \mathrm{C}$, and cotton balls soaked with pathogenic cells were placed under the tongues of the mice for $75 \mathrm{~min}$. On the fifth day, tongues of sacrificed mice were dissected for further analysis using pathological sections and CFU 
analysis. Analysis of CFUs was performed on SDA agar medium (Sabouraud agar plate medium; $40 \mathrm{~g}$ maltose, $10 \mathrm{~g}$ peptone, and $20 \mathrm{~g}$ agar per liter, $\mathrm{pH}$ 6.2). After homogenizing the tongue tissue, an aliquot of $200 \mu \mathrm{L}$ was spread on the SDA plates, and CFUs were determined after $24 \mathrm{~h}$.

Supplementary Materials: The following are available online at http://www.mdpi.com/1660-3397/17/8/442/s1. Figure S1: ESIMS spectrum of compounds 1 and 2; Figure S2: Growth curves of C. albicans cells treated with compound $1(50 \mu \mathrm{g} / \mathrm{mL})$ and compound $2(100 \mu \mathrm{g} / \mathrm{mL})$; Table S1: List of compounds used in this study; Table S2: List of genes differentially expressed in C. albicans treated with compound 2 ( $\log _{2}$ fold change $\geq 1.5$ ); Table S3: PCR primers used in this study.

Author Contributions: Y.D. designed the experiments; L.M., C.S., C.Z., and X.S. performed the assays; Y.D., J.J., and S.S. analyzed the data; L.M., Y.D., and C.S. wrote the manuscript.

Funding: This work was supported financially by grants from the National Natural Science Foundation of China (grant numbers 41706169, 31571969, and 31830099) and the Guangdong Natural Science Funds for Distinguished Young Scholars (grant number 2014A030306015).

Conflicts of Interest: The authors declare no conflicts of interest.

\section{References}

1. Pfaller, M.A.; Diekema, D.J. Epidemiology of invasive candidiasis: A persistent public health problem. Clin. Microbiol. Rev. 2007, 20, 133-163. [CrossRef]

2. Boral, H.; Metin, B.; Döğen, A.; Seyedmousavi, S.; Ilkit, M. Overview of selected virulence attributes in Aspergillus fumigatus, Candida albicans, Cryptococcus neoformans, Trichophyton rubrum, and Exophiala dermatitidis. Fungal Genet. Biol. 2018, 111, 92-107. [CrossRef] [PubMed]

3. Haynes, K. Virulence in Candida species. Trends Microbiol. 2001, 9, 591-596. [CrossRef]

4. Sudbery, P.; Gow, N.; Berman, J. The distinct morphogenic states of Candida albicans. Trends Microbiol. 2004, 12, 317-324. [CrossRef] [PubMed]

5. Fazly, A.; Jain, C.; Dehner, A.C.; Issi, L.; Lilly, E.A.; Ali, A.; Cao, H.; Fidel, P.L., Jr.; Rao, R.P.; Kaufman, P.D. Chemical screening identifies filastatin, a small molecule inhibitor of Candida albicans adhesion, morphogenesis, and pathogenesis. Proc. Natl. Acad. Sci. USA 2013, 110, 13594-13599. [CrossRef] [PubMed]

6. Saville, S.P.; Lazzell, A.L.; Monteagudo, C.; Lopez-Ribot, J.L. Engineered control of cell morphology in vivo reveals distinct roles for yeast and filamentous forms of Candida albicans during infection. Eukaryot. Cell 2003, 2, 1053-1060. [CrossRef] [PubMed]

7. Lo, H.J.; Köhler, J.R.; DiDomenico, B.; Loebenberg, D.; Cacciapuoti, A.; Fink, G.R. Nonfilamentous C. albicans mutants are avirulent. Cell 1997, 90, 939-949. [CrossRef]

8. Mayer, F.L.; Wilson, D.; Hube, B. Candida albicans pathogenicity mechanisms. Virulence 2013, 4, 119-128. [CrossRef]

9. Kumamoto, C.A. Candida biofilms. Curr. Opin. Microbiol. 2002, 5, 608-611. [CrossRef]

10. López-Ribot, J.L. Candida albicans biofilms: More than filamentation. Curr. Biol. 2005, 15, 453-455. [CrossRef]

11. Ramage, G.; Saville, S.P.; Thomas, D.P.; López-Ribot, J.L. Candida biofilms: An update. Eukaryot. Cell 2005, 4, 633-638. [CrossRef]

12. Kojic, E.M.; Darouiche, R.O. Candida infections of medical devices. Clin. Microbiol. Rev. 2004, 17, $255-267$. [CrossRef] [PubMed]

13. Han, T.L.; Cannon, R.D.; Villas-Bôas, S.G. The metabolic basis of Candida albicans morphogenesis and quorum sensing. Fungal Genet. Biol. 2011, 48, 747-763. [CrossRef]

14. Hilmioglu, S.; Ilkit, M.; Badak, Z. Comparison of 12 liquid media for germ tube production of Candida albicans and C. tropicalis. Mycoses 2007, 50, 282-285. [CrossRef] [PubMed]

15. Sharkey, L.L.; McNemar, M.D.; Saporito-Irwin, S.M.; Sypherd, P.S.; Fonzi, W.A. HWP1 functions in the morphological development of Candida albicans downstream of EFG1, TUP1, and RBF1. J. Bacteriol. 1999, 181, 5273-5279. [PubMed]

16. Padovan, A.C.; Chaves, G.M.; Colombo, A.L.; Briones, M.R. A novel allele of HWP1, isolated from a clinical strain of Candida albicans with defective hyphal growth and biofilm formation, has deletions of Gln/Pro and Ser/Thr repeats involved in cellular adhesion. Med. Mycol. 2009, 47, 824-835. [CrossRef] [PubMed] 
17. Stoldt, V.R.; Sonneborn, A.; Leuker, C.E.; Ernst, J.F. Efg1p, an essential regulator of morphogenesis of the human pathogen Candida albicans, is a member of a conserved class of bHLH proteins regulating morphogenetic processes in fungi. EMBO J. 1997, 16, 1982-1991. [CrossRef]

18. Saputo, S.; Kumar, A.; Krysan, D.J. Efg1 directly regulates ACE2 expression to mediate cross talk between the cAMP/PKA and RAM pathways during Candida albicans morphogenesis. Eukaryot. Cell 2014, 13, 1169-1180. [CrossRef]

19. Lane, S.; Birse, C.; Zhou, S.; Matson, R.; Liu, H. DNA array studies demonstrate convergent regulation of virulence factors by Cph1, Cph2, and Efg1 in Candida albicans. J. Biol. Chem. 2001, 276, 48988-48996. [CrossRef]

20. Araújo, D.; Henriques, M.; Silva, S. Portrait of Candida species biofilm regulatory network genes. Trends Microbiol. 2017, 25, 62-75. [CrossRef]

21. Hoyer, L.L.; Cota, E. Candida albicans agglutinin-like sequence (Als) family vignettes: A review of Als protein structure and function. Front. Microbiol. 2016, 7, 280. [CrossRef] [PubMed]

22. Zhang, C.; Sun, C.; Huang, H.; Gui, C.; Wang, L.; Li, Q.; Ju, J. Biosynthetic baeyer-villiger chemistry enables access to two anthracene scaffolds from a single gene cluster in deep-sea-derived Streptomyces olivaceus SCSIO T05. J. Nat. Prod. 2018, 81, 1570-1577. [CrossRef] [PubMed]

23. Sun, C.; Zhang, C.; Qin, X.; Wei, X.; Liu, Q.; Li, Q.; Ju, J. Genome mining of Streptomyces olivaceus SCSIO T05: Discovery of olimycins A and B and assignment of absolute configurations. Tetrahedron 2018, 74, 199-203. [CrossRef]

24. Zhao, P.J.; Li, G.H.; Shen, Y.M. New Chemical Constituents from the Endophyte Streptomyces Species LR4612 Cultivated on Maytenus hookeri. Chem. Biodivers. 2006, 3, 337-342. [CrossRef] [PubMed]

25. Li, Y.; Tang, J.; Gao, H.; Lin, H.; Hong, K.; Yao, X. Study of anti-MRSA bioactive constituents from a marine actinomycetes Micromonospora sp. (No. 69). Chin. J. Mar. Drugs 2010, 29, 16-21.

26. Noble, S.M.; French, S.; Kohn, L.A.; Chen, V.; Johnson, A.D. Systematic screens of a Candida albicans homozygous deletion library decouple morphogenetic switching and pathogenicity. Nat. Genet. 2010, 42, 590-598. [CrossRef] [PubMed]

27. Gulati, M.; Nobile, C.J. Candida albicans biofilms: Development, regulation, and molecular mechanisms. Microbes Infect. 2016, 18, 310-321. [CrossRef]

28. Swinney, D.C.; Anthony, J. How were new medicines discovered? Nat. Rev. Drug Discov. 2011, 10, 507-519. [CrossRef]

29. Guzmán-Chávez, F.; Salo, O.; Nygård, Y.; Lankhorst, P.P.; Bovenberg, R.A.L.; Driessen, A.J.M. Mechanism and regulation of sorbicillin biosynthesis by Penicillium chrysogenum. Microb. Biotechnol. 2017, 10, 958-968. [CrossRef]

30. Bassegoda, A.; Ivanova, K.; Ramon, E.; Tzanov, T. Strategies to prevent the occurrence of resistance against antibiotics by using advanced materials. Appl. Microbiol. Biotechnol. 2018, 102, 2075-2089. [CrossRef]

31. Ezzariai, A.; Hafidi, M.; Khadra, A.; Aemig, Q.; El Fels, L.; Barret, M.; Merlina, G.; Patureau, D.; Pinelli, E. Human and veterinary antibiotics during composting of sludge or manure: Global perspectives on persistence, degradation, and resistance genes. J. Hazard. Mater. 2018, 359, 465-481. [CrossRef] [PubMed]

32. Monroy-Pérez, E.; Sáinz-Espuñes, T.; Paniagua-Contreras, G.; Negrete-Abascal, E.; Rodríguez-Moctezuma, J.R.; Vaca, S. Frequency and expression of ALS and HWP1 genotypes in Candida albicans strains isolated from Mexican patients suffering from vaginal candidosis. Mycoses 2012, 55, 151-157. [CrossRef] [PubMed]

33. Staab, J.F.; Ferrer, C.A.; Sundstrom, P. Developmental expression of a tandemly repeated, proline- and glutamine-rich amino acid motif on hyphal surfaces of Candida albicans. J. Biol. Chem. 1996, 271, 6298-6305. [CrossRef] [PubMed]

34. Ene, I.V.; Bennett, R.J. Hwp1 and related adhesins contribute to both mating and biofilm formation in Candida albicans. Eukaryot. Cell 2009, 8, 1909-1913. [CrossRef] [PubMed]

35. Staab, J.F.; Bradway, S.D.; Fidel, P.L.; Sundstrom, P. Role of Tec1 in the development, architecture, and integrity of sexual biofilms of Candida albicans. Eukaryot. Cell 2015, 14, 228-240.

36. Sahni, N.; Yi, S.; Daniels, K.J.; Huang, G.; Srikantha, T.; Soll, D.R. Tec1 mediates the pheromone response of the white phenotype of Candida albicans: Insights into the evolution of new signal transduction pathways. PLoS Biol. 2010, 8, e1000363. [CrossRef] [PubMed]

37. Nobile, C.J.; Nett, J.E.; Hernday, A.D.; Homann, O.R.; Deneault, J.S.; Nantel, A.; Andes, D.R.; Johnson, A.D.; Mitchell, A.P. Biofilm matrix regulation by Candida albicans Zap1. PLoS Biol. 2009, 7, e1000133. [CrossRef] 
38. Teasdale, M.E.; Liu, J.; Wallace, J.; Akhlaghi, F.; Rowley, D.C. Secondary metabolites produced by the marine bacterium Halobacillus salinus that inhibit quorum sensing-controlled phenotypes in gram-negative bacteria. Appl. Environ. Microbiol. 2009, 75, 567-572. [CrossRef]

39. Reynolds, T.B.; Fink, G.R. Bakers' yeast, a model for fungal biofilm formation. Science 2001, $291,878-881$. [CrossRef]

40. Silva-Dias, A.; Miranda, I.; Branco, J.; Monteiro-Soares, M.; Pina-Vaz, C.; Rodrigues, A.G. Adhesion, biofilm formation, cell surface hydrophobicity, and antifungal planktonic susceptibility: Relationship among Candida spp. Front. Microbiol. 2015, 6, 205. [CrossRef]

41. Clément, M.; Fournier, H.; de Repentigny, L.; Belhumeur, P. Characterization of CaGSP1, the Candida albicans RAN/GSP1 homologue. Gene 2000, 250, 159-169. [CrossRef]

42. Wang, T.; Xiu, J.; Zhang, Y.; Wu, J.; Ma, X.; Wang, Y.; Guo, G.; Shang, X. Transcriptional responses of Candida albicans to antimicrobial peptide MAF-1A. Front. Microbiol. 2017, 8, 894. [CrossRef] [PubMed]

43. Solis, N.V.; Filler, S.G. Mouse model of oropharyngeal candidiasis. Nat. Protoc. 2012, 7, 637-642. [CrossRef] [PubMed]

44. Holtappels, M.; Swinnen, E.; De Groef, L.; Wuyts, J.; Moons, L.; Lagrou, K.; Van Dijck, P.; Kucharíková, S. Antifungal activity of oleylphosphocholine on in vitro and in vivo Candida albicans biofilms. Antimicrob. Agents Chemother. 2017, 62, e01767-e01817. [CrossRef] [PubMed]

(C) 2019 by the authors. Licensee MDPI, Basel, Switzerland. This article is an open access article distributed under the terms and conditions of the Creative Commons Attribution (CC BY) license (http://creativecommons.org/licenses/by/4.0/). 